\title{
Review of Benzene Stripping Alternatives for the Small Tank Precipitation Facility
}

by

C. Caputo (contact)

Westinghouse Savannah River Company

YECEIVED

Savannah River Site

Aiken, South Carolina 29808

L. O. Dworjanyn

This paper was prepared in connection with work done under the above contract number with the U.S. Department of Energy. By acceptance of this paper, the publisher and/or recipient acknowledges the U. S.

Government's right to retain a nonexclusive, royalty-free license in and to any copyright covering this paper, along with the right to reproduce and to authorize others to reproduce all or part of the copyrighted paper. 


\section{DISCLAIMER}

This report was prepared as an account of work sponsored by an agency of the United States Government. Neither the United States Government nor any agency thereof, nor any of their employees, makes any warranty, express or implied, or assumes any legal liability or responsibility for the accuracy, completeness, or usefulness of any information, apparatus, product or process disclosed, or represents that its use would not infringe privately owned rights. Reference herein to any specific commercial product, process or service by trade name, trademark, manufacturer, or otherwise does not necessarily constitute or imply its endorsement, recommendation, or favoring by the United States Government or any agency thereof. The views and opinions of authors expressed herein do not necessarily state or reflect those of the United States Government or any agency thereof.

This report has been reproduced directly from the best available copy.

Available for sale to the public, in paper, from: U.S. Department of Commerce, National Technical Information Service, 5285 Port Royal Road, Springfield, VA 22161

phone: (800) 553-6847

fax: (703) 605-6900

email: orders@ntis.fedworld.gov

online ordering: http://www.ntis.gov/ordering.htm

Available electronically at http://www.doe.gov/bridge

Available for a processing fee to U.S. Department of Energy and its contractors, in paper, from: U.S. Department of Energy, Office of Scientific and Technical Information, P.O. Box 62, Oak Ridge, TN 37831-0062

phone: (865)576-8401

fax: (865)576-5728

email: reports@adonis.osti.gov 


\section{DISCLAIMER}

Portions of this document may be illegible in electronic image products. Images are produced from the best available original document. 
WSRC-RP-99-00426

Revision 0

\title{
Review Of Benzene Stripping Alternatives For The Small Tank Precipitation Facility
}

\author{
L. O. Dworjanyn
}

Publication Date: June 18, 1999

Westinghouse Savannah River Company Savannah River Technology Center Aiken, SC 29808

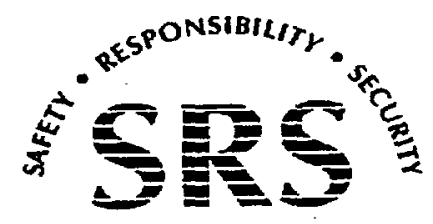




\title{
Review Of Benzene Stripping Alternatives For The Small Tank Precipitation Facility
}

\author{
L. O. Dworjanyn \\ Waste Processing Technology Section \\ Savannah River Technology Center \\ Savannah River Site, Bdg. 735-11A
}

\section{SUMMARY}

Packed columns provide a proven technology for stripping benzene from salt solution. With continuous Small Tank Precipitation process the stripping load is reduced by a factor of four vs. former ITP cycling, and process continuity is maintained through to the Saltstone transfer tank. Lower stripping capacity allows new design options, including coarser packing and possibly reduced foaming packing.

Nitrogen sparging is a cost effective method for stripping benzene from dilute salt solutions. In theory, the sparging gas, dispersed in fine droplets in the solution, is rapidly saturated with benzene. Under Late Wash conditions, sparging was efficient down to $5 \mathrm{mg} / \mathrm{L}$. Stripping to lower concentrations required additional time and stripping under more concentrated Small Tank conditions was not investigated. A key concern is foaming introduced by the gas bubbles, necessitating mechanical foam breakup equipment. Foaming in concentrated salt solutions is particularly problematic since this can lead to "solid stationary foam" difficult to move or disperse. A sparging operation would likely require two tanks, a feed tank and a sparge tank, and would result in a separate batch operation following continuous Small Tank Precipitation. Existing ITP packed columns and Late Wash tanks could be utilized for stripping and sparging.

The opposite of sparging (bubbles of gas in a liquid) would be a shower of liquid droplets in a gas to minimize foaming. This could be achieved in a static column, or dynamically using a vortex scrubbing device.

\section{RECOMMENDATIONS}

1. Consult with industry and equipment manufacturers to identify proven technology for processing concentrated salt solutions and minimizing foaming, including non-foaming column packing, shower columns, and vortex scrubbing.

2. Test selected components for operability and foaming under Small Tank Precipitation processing conditions. 
3. Evaluate feasibility of raising Saltstone benzene acceptance limit from $3 \mathrm{mg} / \mathrm{L}$ to $5 \mathrm{mg} / \mathrm{L}$.

\section{BACKGROUND}

Small Tank Precipitation (STP) process is one of the alternatives for High Level Waste (HLW) salt solution decontamination. As with the original In-Tank Precipitation (ITP) process, sodium tetraphenylborate (NaTPB) and monosodium titanate (MST) would be used to precipitate radioactive cesium-137 and strontium. However the new process would run continuously, in small tanks, and at a controlled temperature, $25^{\circ} \mathrm{C}$, to minimize TPB decomposition and benzene generation. A preliminary flow sheet and material balance prepared by R. A. Jacobs of HLW Process Engineering is shown in Figure 1. The decontaminated salt solution (Figure 1, Stream 9) is assumed to be saturated with benzene at $215 \mathrm{mg} / \mathrm{L}$ at $23^{\circ} \mathrm{C}$ (Ref. 1) and requires stripping to meet 3 $\mathrm{mg} / \mathrm{L}$ acceptance limits for Saltstone operations.

Benzene stripping in a packed column, as used in ITP, and nitrogen sparging, as planned for Late Wash, need re-evaluation for the STP facility, particularly in consideration of a continuous precipitation process and smaller continuous feed rate of decontaminated salt solution, $22 \mathrm{gpm}$ vs. $114 \mathrm{gpm}$ design for batch ITP. The existing smaller ITP stripping column has a design rate of $22 \mathrm{gpm}$.

\section{PACKED COLUMN OPERATIONS}

Operation of packed columns has been demonstrated in ITP and in extensive tests at Koch Engineering (Ref. 2). Benzene is sparingly soluble in concentrated salt solution, about $215 \mathrm{mg} / \mathrm{L}$ in $4.7 \mathrm{M} \mathrm{Na}+$ (Ref. 1) and readily strippable to air or nitrogen. In the STP process the benzene stripper would follow the concentrate cross-flow filter, Figure 2A, Stream 9, maintaining a continuous flow through to the Saltstone transfer tank. Since the stripper would be in continuous use the decontaminated salt solution feed rate would be only $22 \mathrm{gpm}$ vs. $114 \mathrm{gpm}$ for ITP which was based on cyclic campaign operation. For ITP equivalent performance the stripper column diameter could be reduced from 30 to $13 \mathrm{in}$., approximately the size of the smaller, 16 in. diameter, ITP column. Extensive tests at Koch Engineering (Ref. 2) have shown that 100 to $1000 \mathrm{mg} / \mathrm{L}$ benzene in feed can be stripped to under $2 \mathrm{mg} / \mathrm{L}$ with existing ITP design: liquid flow $25 \mathrm{gpm} / \mathrm{ft}^{2}$, nitrogen flow $90 \mathrm{SCFM} / \mathrm{ft}^{2}$.

Key considerations in stripping are foaming and resultant increased column pressure drop which sets a limit on the gas flow. Tests at Koch Engineering (Ref. 2) have shown that the pressure drop can be controlled by addition of antifoam agents, with minimal effect on stripping efficiency.

New design for the STP process offers additional options to assure effective benzene stripping: 
1. Increased column diameter to reduce pressure drop.

2. Coarser packing to reduce pressure drop.

3. Specialized packing to provide laminar or columnar liquid flow, minimizing bubble formation (foaming) when the gas phase is forced to penetrate the liquid phase.

In addition, an in-line continuous stripper would be simpler to operate as part of continuous STP processing.

\section{IN-TANK SPARGING}

Tests on 1/200 scale Late Wash sparging have shown that benzene can be readily removed from low sodium concentration salt solution by batch sparging in an agitated vessel (Ref. 3). Late wash test data showed that benzene concentration during sparging of salt solution falls off exponentially with purge time, down to about $5 \mathrm{mg} / \mathrm{L}$, indicating vapor phase diffusion or liquid/vapor interface control (Figure 3). However, below $5 \mathrm{mg} / \mathrm{L}$ the stripping efficiency falls off rapidly, indicating slower liquid phase diffusion control. The effectiveness of benzene stripping from high sodium salt solutions has not been investigated. Assuming Late Wash data, Small Tank sparging time can be estimated down to about $5 \mathrm{mg} / \mathrm{L}$ as calculated in Table 1 and shown in Figure 4.

A major concern in sparging is foaming. A test designed for evaluating foaming in Late Wash was abandoned due to uncontrolled foaming in an 8 in. un-agitated column (Ref. 5). In earlier Late Wash filtration testing (Ref. 9), foaming was introduced by simulated ITP slurry recirculation and Surfynol ${ }^{\circledR}$ had to be used to control foaming. Stationary ITP foam formed around the edges of the recirculation container. The foam solidified with time as the solution concentrated by evaporation. The same could occur by channeling in sparging, allowing stationary foam to evaporate and solidify.

Sparging by definition, is making bubbles in the solution. This in turn leads to foaming. Controlled agitation and/or foam break up equipment could be needed to permit reliable sparging.

The STP sparging process would require two tanks: a decontaminated salt solution receipt tank, and a batch sparging tank (Figure 2B). Existing tanks in Late Wash facility could be used. Both tanks could be designed for sparging. Using Late Wash data, a one day production of decontaminated salt solution, $32 \mathrm{~K}$ gal, could be stripped to $1 \mathrm{mg} / \mathrm{L}$ in about six hours (Appendix A, Figure 3), assuming 50\% saturation of nitrogen with benzene, no drop off in efficiency below $5 \mathrm{mg} / \mathrm{L}$, and no foaming.

\section{ALTERNATE TECHNOLOGIES}

Since foaming is known to occur during solution and gas mixing, the goal is to identify processes which eliminate or minimize foaming. An example would be a wetted wall column where the liquid flows down the wall and the gas flows up the center without 
breaking through the liquid. This type of stripping is good for studying mass transfer, but the process is inefficient.

A practical approach may be to identify non-foaming packing which generates columnar liquid streams or droplets, allowing the gas to flow by without breaking through liquid sheets which leads to foaming.

Another option is engineered power scrubbing, such as AEA Technology "Vortex Scrubber" (Ref. 6). This scrubber forms a planar stream of droplets by impinging two opposing streams against each other. The scrubbing gas is fed tangentially and exits along the axis of the scrubber (Figure 5). This device is compact, has no moving parts, and requires no demister. This is particularly important in handling concentrated salt solutions.

\section{REFERENCES}

1. D. D. Walker, "Benzene Solubility - - Preliminary Report (U)", SRT-LWP-94-005, 3/28/1994

2. G. K. Georgeton, T. P. Gaughan. G. A. Taylor, "Pilot Scale Benzene Stripping Column Testing: Review of Data and Application to the ITP Columns", WSRC-TR93-468, 9/10/93

3. M. A. Baich, "Qualification of Data - $1 / 200$ th Scale SRAT Late Wash Permeate Sparging (U)", WSRC-RP-93-229, 1/20/93

4. L. O. Dworjanyn, "ITP Filtrate Benzene Removal Alternatives (U)", WSRC-RP-93$767,5 / 21 / 1993$

5. M. A. Baich, "Late Wash Permeate Foam Column", SRTC-PTD-93-114, 11/5/1993.

6. J. N. Brooke, AIChE Meeting - Unpublished, WSRC-MS-98-0067

7. D. D. Walker, "Viscosity and Density of Simulated Salt Solutions (U)", WSRC-RP89-1088.

8. D. D. Walker, "Vapor Pressure of Benzene, Methanol, and Isopropanol Over Salt Solutions (U)", DPST-88-661, 3/28/1989.

9. L. O. Dworjanyn and M. F. Morrissey, "Initial Technical Basis for the Use of Spare ITP Filter in DWPF Late Washing (U)", WSRC-RP-92-766, 6/5/1992. 


\section{AUTHOR}

L. O. Dworjanyn, Advisory Scientist

Date

Liquid Waste Processing Technology

\section{DESIGN CHECK}

R. F. Swingle,

Date

Liquid Waste Processing Technology

\section{APPROVALS}

S. D. Fink, Manager Date

Liquid Waste Processing Technology

J. T. Carter, Manager

Date

Process Engineering

W. L. Tamosaitis, Manager

Date

Waste Processing Technology 
Table 1. Small Tank Sparging Calculations

D:lapp|BZStripYSmall Tank Strip.xls]Table1

Decon Solution Volume Decon Solution Volume Tank Sparge Diameter

Tank Sparge Area

Purge Rate

Nitrogen Flow

Efficiency

Sodium Conc, Na+ Molar

Temperature

Henry's Constant

Starting Benzene Conc
ASSUME

Eqn Synb

V

$$
32342 \text { gal }
$$$$
==\text { Hight }
$$

$S$

E

H

$50 \%$

4.7

CALCULATE

$4324 \mathrm{CF}$

$17.66 \mathrm{FT}$

244.87 SF

73.46 SCFM

$23 \operatorname{deg} C$

1.80 (mq/L in Vapor)/(mg/L in Solution)

$\begin{array}{llll}100 & 120 & 215 & 500\end{array}$

Time Benzene Concentration at Time

$\begin{array}{rrrrrr}\text { MIN } & \text { HR } & 100 \mathbf{~ m g} / \mathbf{L} & 120 \mathbf{~ m g} / \mathbf{L} & \mathbf{2 1 5} \mathbf{~ m g} / \mathbf{L} & 500 \mathbf{~ m g} / \mathbf{L} \\ 0 & 0 & 100.00 & 120.00 & 215.00 & 500.00 \\ 30 & 0.5 & 63.21 & 75.85 & 135.90 & 316.04 \\ 60 & 1 & 39.95 & 47.94 & 85.90 & 199.77 \\ 90 & 1.5 & 25.25 & 30.30 & 54.30 & 126.27 \\ 120 & 2 & 15.96 & 19.16 & 34.32 & 79.81 \\ 150 & 2.5 & 10.09 & 12.11 & 21.69 & 50.45 \\ 180 & 3 & 6.38 & 7.65 & 13.71 & 31.89 \\ 210 & 3.5 & 4.03 & 4.84 & 8.67 & 20.16 \\ 240 & 4 & 2.55 & 3.06 & 5.48 & 12.74 \\ 270 & 4.5 & 1.61 & 1.93 & 3.46 & 8.05 \\ 300 & 5 & 1.02 & 1.22 & 2.19 & 5.09 \\ 330 & 5.5 & 0.64 & 0.77 & 1.38 & 3.22 \\ 360 & 6 & 0.41 & 0.49 & 0.87 & 2.03 \\ 390 & 6.5 & 0.26 & 0.31 & 0.55 & 1.29 \\ 420 & 7 & 0.16 & 0.20 & 0.35 & 0.81 \\ 450 & 7.5 & 0.10 & 0.12 & 0.22 & 0.51 \\ 480 & 8 & 0.06 & 0.08 & 0.14 & 0.32\end{array}$


Figure 1 Small Tank Precipitation Material Balance

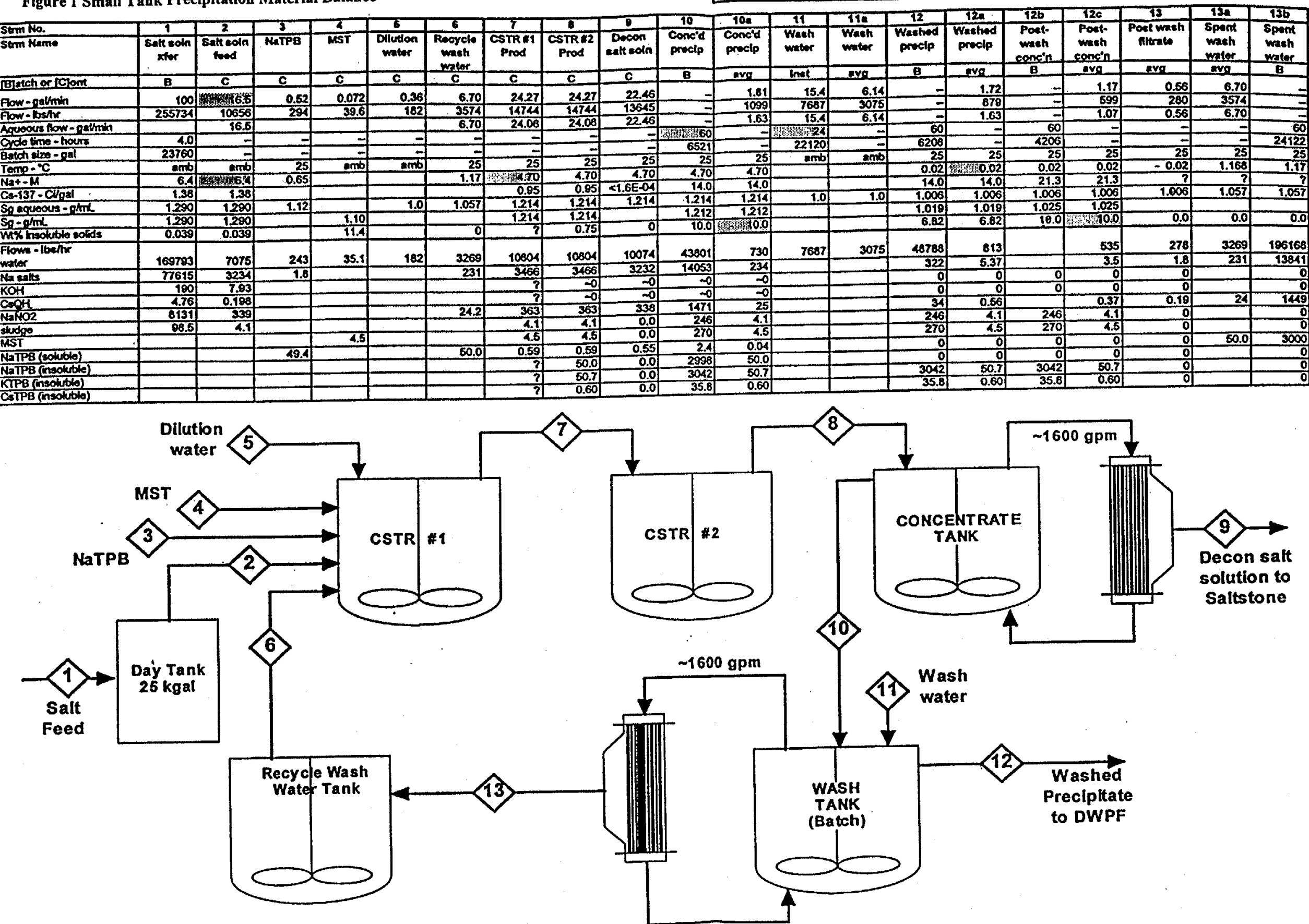


L. O. Dworjanyn

Figure 2

Small Tank Precipitation Process

Benzene Stripping Alternatives

Figure 2A Continuous Stripping in Packed Column -

(9)

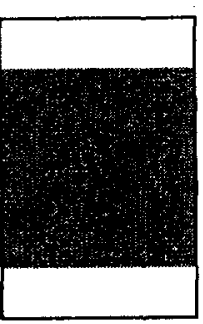

$\mathrm{N}_{2}$

Stripper

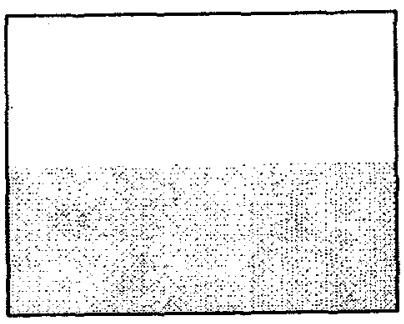

Saltstone Transfer

Figure 2B Batch Sparging of Benzene

(9)

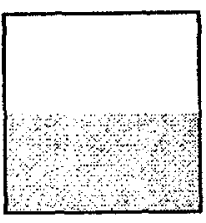

Receipt

Tank
$\mathrm{N}_{2}$

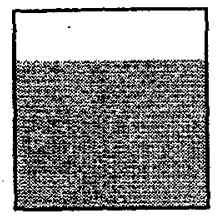

Sparging

Tank

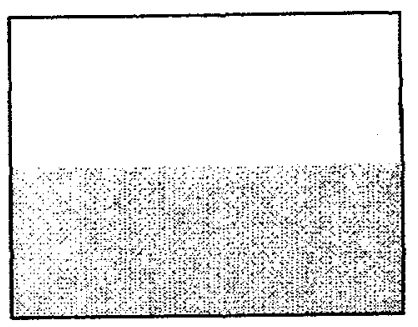

Saltstone Transfer 
Figure 3 Late Wash Test Data, Run \#3.

Late Wash Sparging

Mark Baich, Test Run \#3

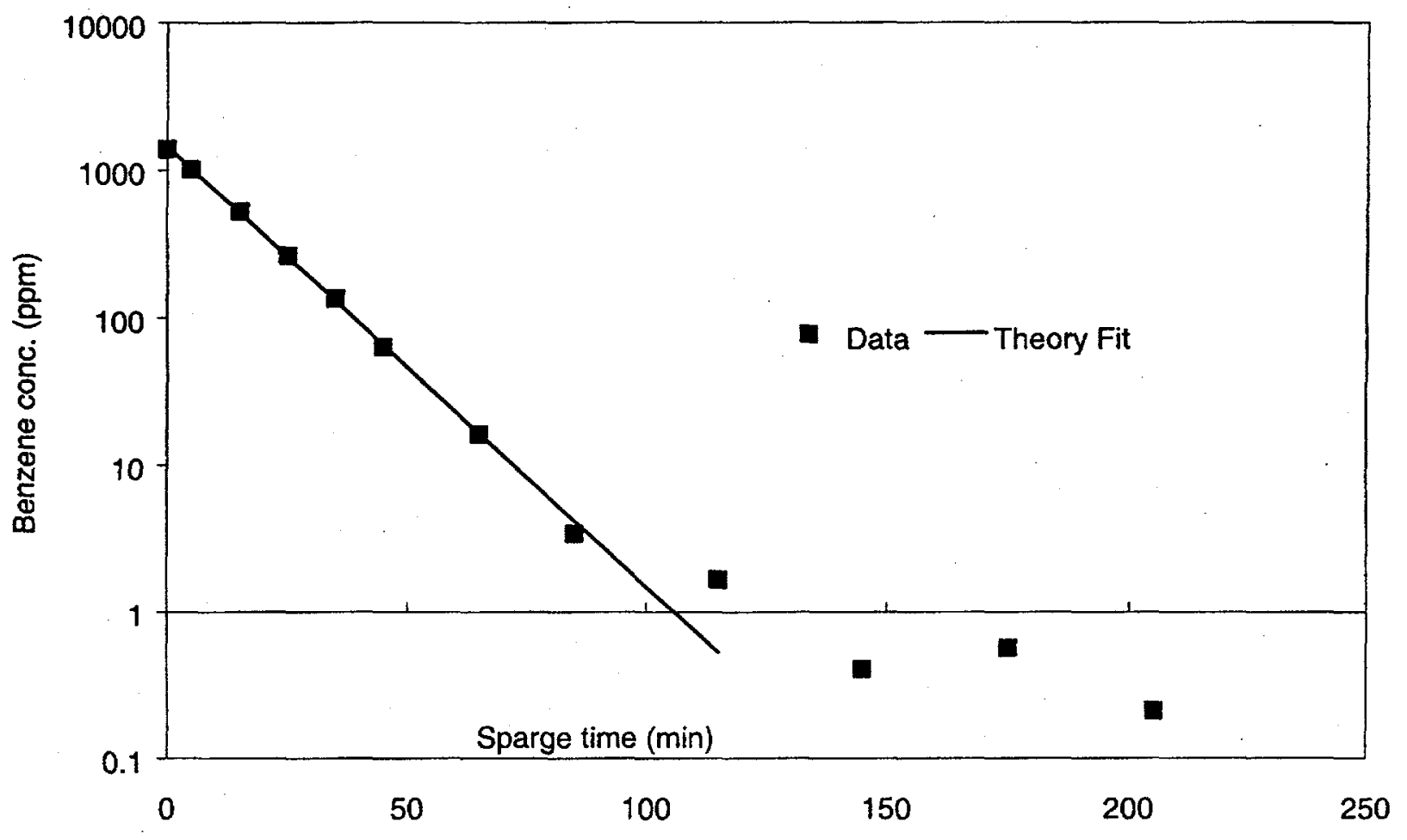


Figure 4 Small Tank TPB Process Sparging

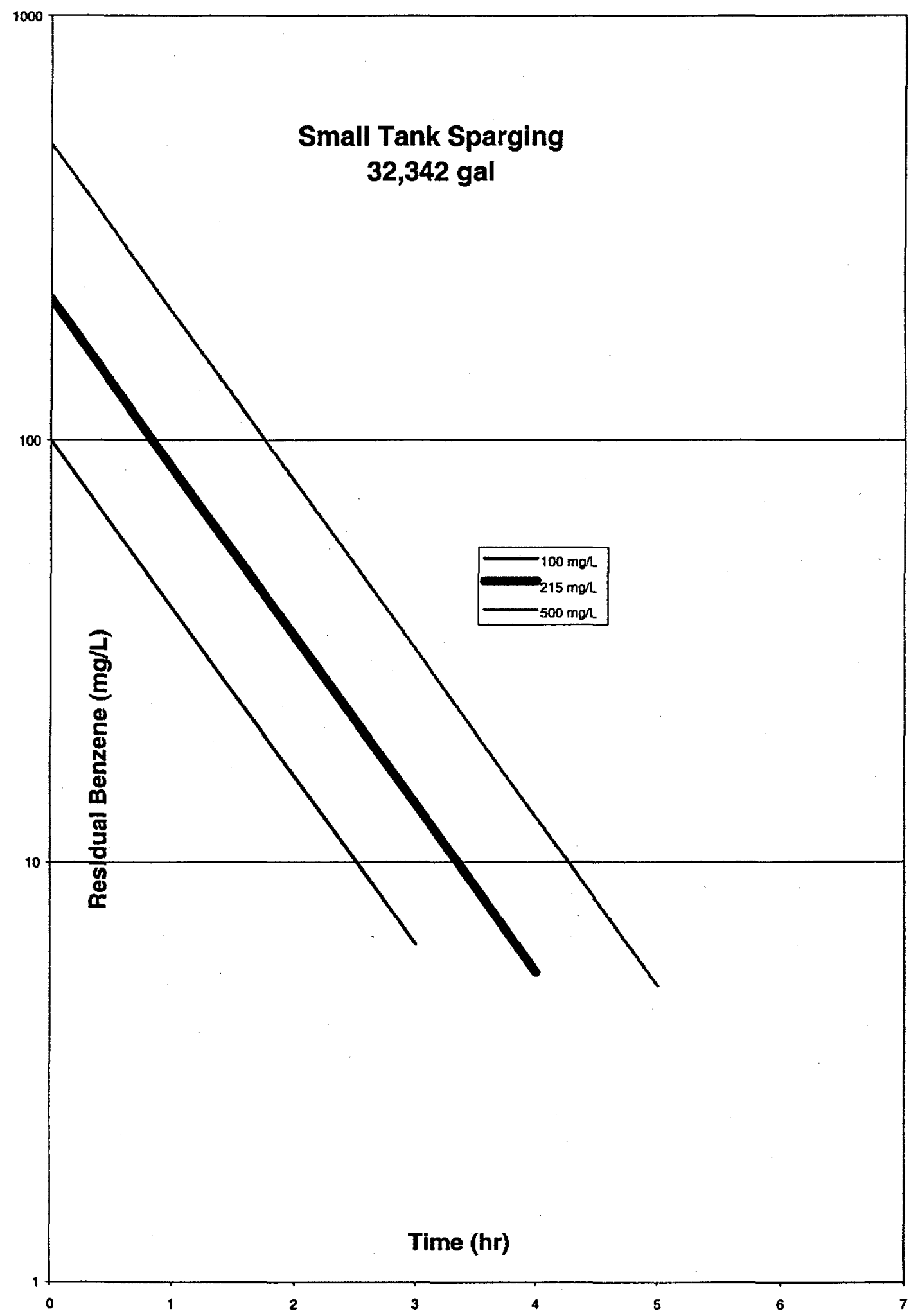




\section{Figure 5 AEA Vortex Scrubber}

AEA: The fluidic gas-liquid contactor uses high tangential gas velocities to provide good mass transfer and disentrain liquid droplets. Vertically-opposed liquid jets supported by fluidic oscillator provide a flat symmetrical pattern of droplets.

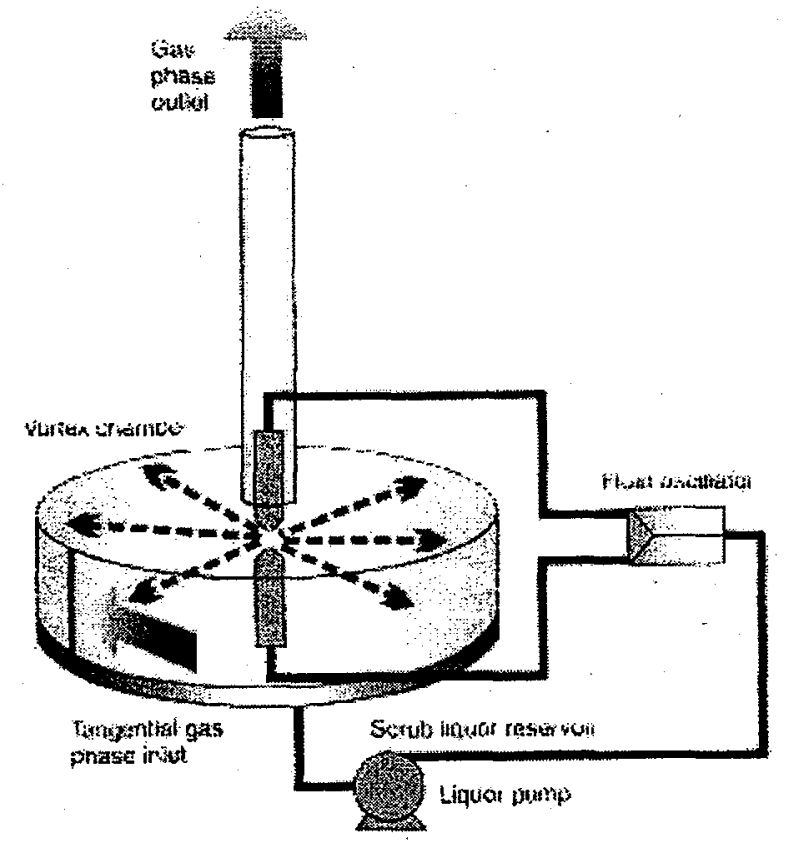

AEA: Velocity vectors and droplet trajectories within the vortex chamber. As the gas spins towards the center its velocity increases, improving mass transfer and imparting tangential velocity to the liquid droplets.

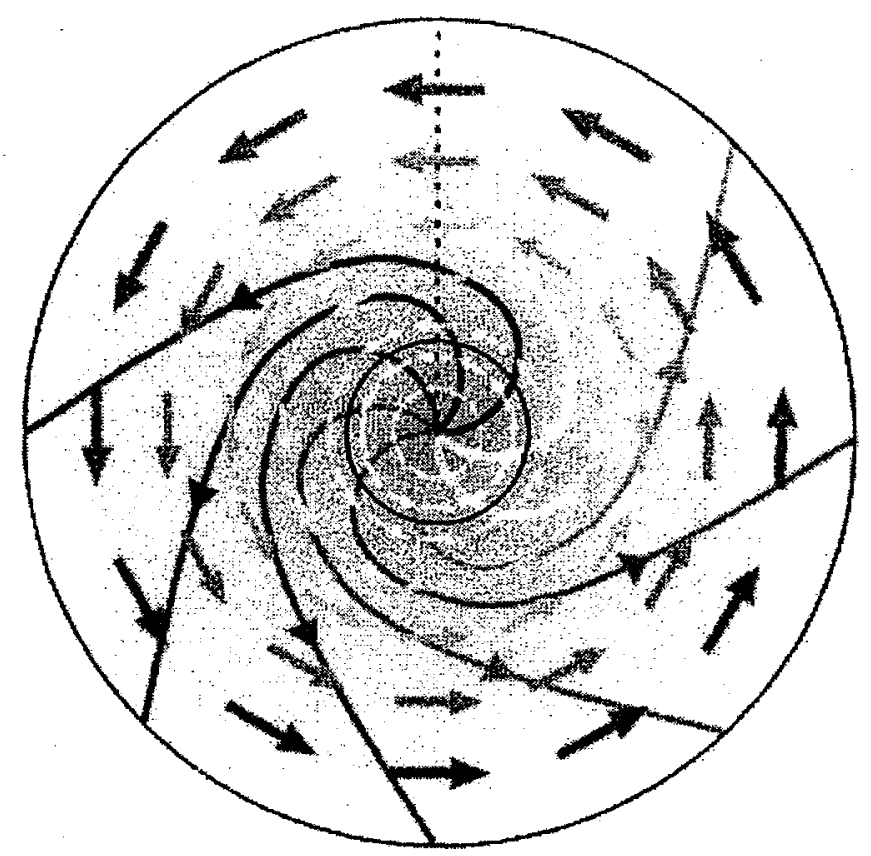


APPENDIX A

SPARGING CALCULATIONS

1. Basic Data: Small Tank TPB Precipitation Material Balance, Figure 2.

NaTPB Excess: $\quad 100 \%$

Decon Salt Solution Flow: $\quad \mathbf{2 2 . 4 6} \mathrm{gal} / \mathrm{min}$, Stream 9

Sodium Concentration: $\quad \mathbf{4 . 7 0} \mathrm{M}$

\section{Physical Properties.}

Solution Density @ 23ำ:

$$
\begin{aligned}
\rho & =1.009+0.04454[\mathrm{Na}+] \quad \mathrm{mg} / \mathrm{L} \quad \text { (Ref. 7) } \\
& =1.009+0.04454 * 4.70 \\
& =1.218 \mathrm{mg} / \mathrm{L}
\end{aligned}
$$

Benzene Solubility @ 23ำ:

$$
\begin{aligned}
\text { Solubility } & =1.7689 * \exp \left(-0.4481\left[\mathrm{Na}^{+}\right]\right) \mathrm{g} / \mathrm{L}(\text { Ref. } 8) \\
& =1.7689 * 0.1217=0.215 \mathrm{~g} / \mathrm{L} \\
& =215 \mathrm{mg} / \mathrm{L}
\end{aligned}
$$

Henry's Law Constant @ 23ㄷ: (Ref. 8)

$\begin{array}{lrrrrrrrrrrr}\mathrm{Na}+ & 0 & 1 & 2 & 3 & 3.5 & 4 & 4.5 & 4.9 & 5 & 5.5 & 6 \\ \mathrm{H} & 0.21 & 0.32 & 0.51 & 0.8 & 1 & 1.24 & 1.56 & 1.87 & 1.96 & 2.45 & 3.07\end{array}$

Henry's constant, $\mathbf{H}=\mathbf{1 . 8 0}(\mathrm{mg} / \mathrm{L}$ in Vapor $) /(\mathrm{mg} / \mathrm{L}$ in Solution) for $4.70 \mathrm{M}[\mathrm{Na}+]$

\section{Vapor Liquid Equilibrium}

Partial Vapor Pressure of benzene over salt solution is given by Henry's Law:

$$
\begin{aligned}
& P_{B}=H * X_{B} \\
& \text { Where } P_{B}=\text { partial pressure of benzene } \\
& \quad X_{B}=\text { mole fraction of benzene in solution } \\
& H=\text { Henry's constant }
\end{aligned}
$$




\section{$4 \quad$ Nitrogen Sparging.}

Based on Late Wash solution testing (Ref. 3), the residual benzene concentration in sparged salt solution is given by:

$$
\mathrm{C}(\mathrm{T})=\mathrm{C} 0 \exp (-\mathrm{SHET} / \mathrm{V})
$$

Where $\mathrm{C}(\mathrm{T})=$ benzene concentration at time $\mathrm{T}(\mathrm{min}), \mathrm{mg} / \mathrm{L}$

$\mathrm{CO}=$ Initial benzene concentration, $\mathrm{mg} / \mathrm{L}$

$S=$ Nitrogen flow, SCFM (Standard ft3/min)

$\mathrm{H}=$ Henry's constant

$\mathrm{V}=$ Decontaminated solution volume, $\mathrm{CS}(\mathrm{ft} 3)$

$E=\quad$ Stripping efficiency 